\title{
Determinants Levels of Urinary 8-Hydroxydeoxyguanosine among Chromium Electroplating Workers
}

\author{
Yuliani Setyaningsih ${ }^{1}$, Indwiani Astuti ${ }^{2}$, Adi Heru Husodo ${ }^{3}$ \\ ${ }^{1}$ Public Health Faculty, Universitas Diponegoro, Semarang, Indonesia \\ ${ }^{2,3}$ Medical Faculty, Universitas Gadjah Mada, Yogyakarta, Indonesia
}

\begin{tabular}{l} 
Article Info \\
\hline Article history: \\
Received Oct 12, 2016 \\
Revised Nov 20, 2016 \\
Accepted Nov 26, 2016 \\
\hline
\end{tabular}

Keyword:

8-OHdG

Chromium

Malondiadehyd

Occupational disease

Smoking

\begin{abstract}
Electroplating workers were exposed by particulate and fog of chromium from electrolysis process during work. Chromium is highly carcinogenic when inhaled. Chromium can be reduced in the cells in the body. This process may generate Reactive Oxygen Species (ROS) causing lipid peroxidation and oxidative DNA damage. This research was aimed to analyze the influence of chromium to the levels of urinary 8-OHdG as an indicator to support early diagnosis of occupational disease. 66 electroplating workers in Tegal District were taken purposively as samples for this research. There were association between chromium level in urine, MDA level, Body Mass Index, smoking habit, alcohol and supplementt drink consumption and urinary $8-\mathrm{OHdG}(\mathrm{p}<0.05)$. There wasn't association between BMI and urinary $8-\mathrm{OHdG}(\mathrm{p}>0.05)$. Multivariate analysis using logistic regression showed the alcohol consumption had the most powerful influence to the level of urinary $8-\mathrm{OHdG}$. The levels of urinary $8-\mathrm{OHdG}$ could be used as an indicator of oxidative DNA damage and early diagnosis of occupational disease among electroplating workers who were exposed by chromium.
\end{abstract}

Copyright @ 2016 Institute of Advanced Engineering and Science. All rights reserved.

\section{Corresponding Author:}

Yuliani Setyaningsih,

Public Health Faculty,

Universitas Diponegoro,

J1 Prof Soedarto SH Tembalang, Semarang-50275, Indonesia.

Email: joeliani_kesja_undip@yahoo.com

\section{INTRODUCTION}

Chromium $(\mathrm{Cr})$ is often used in metal plating process. The purpose of this coating is to make metal rustproof and to increases gloss [1-2]. $\mathrm{Cr}$ (VI) is a strong oxidant and has a potential health hazard. Electroplating workers in the informal sector may inhale chromium in the form of gas, dust and particles when working in or around the electroplating bath. If inhaled and enters the body, Chromium can be reduced valence trivalent form by $\mathrm{Cr}(\mathrm{V})$ and $\mathrm{Cr}(\mathrm{IV})$. This process often generates free radicals, which in turn activates $\mathrm{O}_{2}$ and produce some of Reactive Oxygen Species (ROS). Excess production of ROS can cause lipid peroxidation and oxidative DNA damage [3-6]. Exposure to $\mathrm{Cr}$ (VI) can lead to a variety of DNA mutations and chromosomal damage, and oxidative changes in proteins [7].

Lipid peroxidation can break the membrane phospholipids contain PUFA (Poly Unsaturated Fatty Acids). The increasing of malondialdehyde (MDA) is the most common used as biomarker of lipid peroxidation. MDA is a natural product of lipid peroxidation and prostaglandin biosynthesis that caused mutagenic and carcinogenic. MDA reacts with DNA to form adducts of deoxyguanosine and deoxyadenosine [8].

Oxidative DNA damage form can be determined by measuring levels of 8-OHdG in the urine [9]. 8-OHdG levels are affected by many factors, such as species, sex, age, exercise, alcohol, smoking, Body Mass Index (BMI) [10]. 
Level of $8-\mathrm{OHdG}$ in urine as a biomarker of oxidative DNA damage can be measured by enzyme-linked immunosorbent assay (ELISA) [11] and can be used as an indicator of biologically active dose on low and medium exposure of Chromium hexavalent [12]. This research was aimed to analyze the influence of urinary chromium, MDA, BMI, smoking habits, alcohol and supplement drink consumption to the levels of $8-\mathrm{OHdG}$ in the urine as an indicator to support early diagnosis of occupational disease among electroplating workers.

\section{RESEARCH METHOD}

\subsection{Subject and materials}

This was an observational research with cross sectional design. The study was conducted on workers in the informal centers of electroplating in Tegal, Central Java. There were 66 male workers were altogether taken as a subject. The inclusion criterion was workers who had been exposed to chromium for a year, due to chronic exposure to chromium can be detected after one year.

A total of $10 \mathrm{~mL}$ of respondents' urine were collected after 4 hours of work. The urine was divided into three containers that had been added nitric acid and stored in a polypropylene container at $-20{ }^{\circ} \mathrm{C}$. Levels of urinary chromium were measured by flameless atomic absorption spectrophotometer (AAS) with a graphite furnace (GF-3000) and auto-sampler (PAL-3000). The malondiadehyd level was measured by Tiobarbituric Acid Reactive Substance (TBARS) method. Smoking habit was identified using Brinkman Index.

The levels of 8-OHdG was detected using an ELISA test according to manufacturer's instructions (CUSABIO, China). The concentration was adjusted by urinary creatinine levels. A questioner was used to collect worker characteristic data such as age, nutritional status (BMI), alcohol and supplement drink consumption.

\subsection{Statistical analysis}

Chi square test was used to analyse bivariate data including chromium levels in urine, MDA level, BMI, smoking habits, alcohol and supplement drink consumption and levels of urinary 8-OHdG. Logistic regression was used to analyse the factors affected the levels of urinary 8-OHdG.

\subsection{Ethical approval}

Ethical clearance to conduct this study was approved by Medical and Health Research Ethics Committee (MHREC), Medicine Faculty, Gadjah Mada University, Dr. Sardjito Hospital (Ref : KE / FK / 993 / EC).

\section{RESULTS AND ANALYSIS}

\subsection{Bivariate analysis}

Respondents' ages in this study were between 17-56 years old. All respondents did not use personal protective equipment, such as masks, long-sleeved shirts or boots. There were $56.1 \%$ of workers who directly deal with electroplating bath in the production room as it works as dyeing. As for the working period, it ranges from 1 to 40 years. Urinary chromium levels of respondents ranged between $2.811 \mu \mathrm{g} / \mathrm{L}-145.340 \mu \mathrm{g} / \mathrm{L}, \mathrm{MDA}$ levels in the workers' urine were between $0.016 \mu \mathrm{mol} / \mathrm{L}-1.950 \mu \mathrm{mol} / \mathrm{L}$. While the levels of urinary $8-\mathrm{OHdG}$ ranged from $1.079 \mathrm{ng} / \mathrm{mL}-974.990 \mathrm{ng} / \mathrm{mL}$.

Table 1 shows the results of bivariate analysis. There were $51.51 \%$ of respondents whose urinary chromium level were more $10 \mu \mathrm{g} / \mathrm{L}$. In addition, $72.73 \%$ of respondents had MDA level more $0.23 \mu \mathrm{mol} / \mathrm{L}$. This value was higher than the normal range for urinary chromium in humans ranging from $0.1 \mathrm{mg} / \mathrm{L}-0.5 \mathrm{mg} / \mathrm{L}$ [13]. Respondents were also more likely to smoke during work (53.03\%). There were as many as 20 people $(30.30 \%)$ of respondents who drank alcohol and 17 respondents $(25.76 \%)$ were taking supplement drink. Bivariate analysis showed the levels of urinary chromium, MDA levels in the urine, smoking habits, alcohol consumption and supplement drink related to the levels of urinary 8-OHdG $(\mathrm{p}<0.05)$. Only the nutritional status (BMI) was not related to the levels of urinary 8-OHdG. There were $72.7 \%$ of workers with MDA levels of more than $0.23 \mathrm{~mol} / \mathrm{L}$ and $54.5 \%$ of workers who had $8-\mathrm{OHdG}$ levels greater $24.5 \mathrm{ng} / \mathrm{mL}$. MDA levels in the body can be used as an indicator to determine the oxidative stress in humans as the result of lipid peroxidation [8]. 
Table 1. Bivariate Analysis between Levels of Urinary Chromium, MDA, BMI, Smoking, Alcohol and Supplement Drink Consumption with Levels of Urinary 8-OHdG

\begin{tabular}{lcrrr}
\hline \multicolumn{1}{c}{ Variabels } & $\mathrm{N}(\%)$ & $P$ & $\mathrm{OR}$ & $95 \% \mathrm{CI}$ \\
\hline Urinary Chromium & & 0.028 & 3.056 & $1.116-8.365$ \\
$\quad \geq 10 \mu \mathrm{g} / \mathrm{L}$ & $34(51.51)$ & & & \\
$\quad<10 \mu \mathrm{g} / \mathrm{L}$ & $32(48.49)$ & & & \\
MDA levels & & 0.034 & 3.333 & $1.065-10.433$ \\
$\quad \geq 0.23 \mu \mathrm{mol} / \mathrm{L}$ & $48(72.73)$ & & & \\
$\quad<0.23 \mu \mathrm{mol} / \mathrm{L}$ & $18(27.27)$ & & & \\
Body Mass Index & $32(48.49)$ & & & \\
$\quad$ Abnormal & $34(51.51)$ & & & \\
$\quad$ Normal & $35(53.03)$ & & & \\
Smoking Habit & $31(46.97$ & & & \\
$\quad$ Heavy smoker & & & & \\
$\quad$ Light smoker & $20(30.30)$ & & & \\
Drinking of alcohol & $46(69.7)$ & & & \\
$\quad$ Yes & & & & \\
$\quad$ No & $17(25.76)$ & & & \\
Supplementation habit & $49(74.24)$ & & & \\
$\quad$ Yes & & & & \\
$\quad$ No & & & & \\
\hline
\end{tabular}

Urinary chromium can be used as indicator of absorption during 1 to 2 days before the test [14]. All levels of urinary chromium were higher than normal levels in the human body and $34 \%$ of respondents had a chromium content of more than $10 \mathrm{mg} / \mathrm{mL}$ or exceeds permissible levels in the body. Bivariate test results showed that there were an association between urinary chromium levels with levels of urinary 8-OHdG. Zhang stated that low exposure of chromium can cause oxidative DNA damage as evidenced by the existence of urinary 8-OHdG [11]. Electroplating workers were exposed to hexavalent chromium particles and mist generated from electrolysis process that occurs in the electroplating bath. The particles and mist occurred as a result of a burst on the surface of the liquid in the electroplating bath derived from oxygen and hydrogen bubbles out of the current electrode coating process [15].

\subsection{Multivariate analysis}

Table 2 shows that smoking, alcohol and supplement drink consumption were associated with levels of urinary 8-OHdG. Variable of drinking alcohol had the lowest significant level compared to all other variables $(\mathrm{p}=0.001)$. The relationship between smoking habits, alcohol and supplement drink consumption to the levels of $8-\mathrm{OHdG}$ can be seen from the logistics test results. Alcohol consumption had the strongest influence toward oxidative DNA damage compared to other variables. Alcohol consumption had the Exp $(\beta)$ or OR value was 2.883, which means that electroplating workers who had drink alcohol habit were likely to have 2.883 times the risk for oxidative DNA damage.

Tabel 2. Summary of Logistic Regression Results that is Statistically Significant

\begin{tabular}{lcccc}
\hline \multicolumn{1}{c}{ Variable } & $\mathrm{B}$ & $p$ & Adjusted OR & $95 \%$ CI \\
\hline Smoking habit & 1.497 & 0.021 & 4.470 & $1.255-15.929$ \\
Alcohol consumption & 2.883 & 0.001 & 17.864 & $3.128-102.017$ \\
Supplement drink consumtion & 1.471 & 0.067 & 4.353 & $0.903-20.992$ \\
Constant & -10.112 & & & \\
\hline
\end{tabular}

When chromium entered the body, the valence of chromium will changes that will be a trigger oxidants such as ROS. The increasing of ROS in the body will cause lipid peroxidation which is characterized by elevated levels of MDA in the urine and will cause oxidative DNA damage [16-17].

Smoking, alcohol and supplement drink consumption were associated with higher levels of urinary 8-OHdG. Heavy smokers have a risk 3.455 times more likely to have urinary 8-OHdG more than $24.5 \mathrm{ng} / \mathrm{mL}$. While workers who drink alcohol have a risk 14 times to have 8 -OHdG more than $24.5 \mathrm{ng} / \mathrm{mL}$. Workers who taking supplements drink have a risk of 5,724 times to have 8-OHdG more than $24.5 \mathrm{ng} / \mathrm{mL}$.

Psychology capacity like smoking habit, alcohol and suplement drink consumption greatly affected the performance and productivity of worker. Variable of psychology capacity in the measurement model in this study was formed by indicators of smoking, alcohol and supplements drink consumption. This present study consistent with Zhang who stated there was an effect between smoking and supplement drink 
consumption to increase the level of urinary $8-\mathrm{OHdG}$ in workers who exposed to chromium electroplating [11].

This present study was consistent with research conducted by Nielsen et al, which stated that there was a relationship between MDA and smoke exposure cigarettes [18]. Long term alcohol consumption was a major risk factor for heart disease in humans. Long term consumption of ethanol in a large amount will lead to cirrhosis and liver dysfunction. Liver dysfunction can also inhibit the detoxification of the ingested carcinogenic compound. By producing ROS, ethanol can affect the nutritional status and liver function, immune function and other body functions that can affect the risk of various cancers [19].

Smoking, alcohol and supplement drink consumption related to the levels of urinary 8-OHdG ( $\mathrm{p}<0.05$ ). Smokers prone to have respiratory disorder compared to non smokers when they were in hazardous environment. There were 2000 chemicals in the cigarrette, and 1200 of them contain toxic substances for human health. Besides that, exposure to cigarette smoke have strong relations with the DNA damage induced by oxidative stress (oxidative stress) and carcinogenesis [20]. Smoking was known to increase levels of free radicals that trigger the destruction of DNA and various oxidized bases (e.g. 8-oxoguanosine). Some studies indicate the role of smoking in the growth of cancer in humans, such as lung cancer, mouth, pharynx, laring, esophagus, bladder, stomach, pancreas, kidney, uterus, cervix and myeloid leukemia [21]. It was found that the free radicals produced during the process of auto oxidation of polyphenols in the salivary fluid of smokers. It was very crucial to the initiation stage of cancer of the mouth, pharynx, larynx and esophagus. More specifically, it also can cause oxidation of glutathione (GSH, antioxidant protecting DNA from damage caused by ROS), lower antioxidant levels in the blood and increase the release of superoxide radicals [22].

While the ability of alcohol to induce lipid peroxidation was associated with DNA damage caused directly or indirectly by ethanol or a metabolite acetaldehyde. The ability of ethanol to produce the formation of free oxygen and ROS can caused lipid peroxidation by increasing retention of antioxidants and asetadehida to stimulate lipid peroxidation either directly through the formation of free radicals or by decreasing the concentration of antioxidants [23]. Ethanol was normally metabolized to acetaldehyde, through the transfer of hydrogen with oxidative alcohol dehydrogenase (ADH), which was reduced to NADH by the microsomal ethanol oxidizing system. Xanthine oxidase oxidized asetildehid was formed by the metabolism of ethanol and producedv ROS. Therefore, ethanol was capable to produce ROS during metabolism. ROS were highly reactive, because they had unpaired electron. Ethanol also increased the production of superoxide anion and hydroxyl radicals, which reacted rapidly with biological material, causing oxidative damage to organisms [19].

One of the ingredients that quite high on the supplement drink was caffeine. Besides caffeine, supplement drink also contained additives such as artificial sugar or aspartame, guarana and ginseng may enhance the effects of caffeine. Caffeine makes the organism alert and presses the fatigue threshold. As a result, workers do not have the verge of exhaustion as a defence mechanism to break. A body that was constantly forced to work will be fatigue even before the work starts. WHO stated that working period and working hours per day in hazardous environment will have a great potential for the occurrence of occupational diseases [24]. The longer of working period and working hours per day, the greater the potential of chemical exposure compared to those who had shorter working period and working hours per day. High level of urinary $8-\mathrm{OHdG}$ can be used as an indicator of oxidative DNA damage [15].

\section{CONCLUSION}

Smoking, drinking alcohol and taking supplement drink can increase the level of urinary 8-OHdG on workers who exposed to chromium in the electroplating informal sectors. Oxidative DNA damage can be detected by measurement of the level of urinary 8-OhdG. 8-OHdG may be use as indicator in early diagnosis of occupational disease among electroplating workers who are exposed by chromium.

\section{ACKNOWLEDGEMENTS}

The authors would like to thank to the Ministry of Research and Technology and Higher Education of the Republic of Indonesia, which has provided the doctoral scholarship program; Biochemistry and Parasitology Laboratory of Medical Faculty, Universitas Gadjah Mada in Yogyakarta; and BBTKLPP for analysing urinary chromium. 


\section{REFERENCES}

[1] A. Gambelunghe, et al., "Primary DNA damage in chrome-plating workers," Toxicology, vol. 188, pp. 187-195, 2003.

[2] A. Caglieri, et al., "The effect of inhaled chromium on different exhaled breath condensate biomarkers among chrome-plating workers," Environ Health Perspect, vol/issue: 114(4), pp. 542-6, 2006.

[3] U. H. Danielson, et al., "Structure-activity relationships of 4 hydroxyalkenals in the conjugation catalysed by mammalian glutathione transferases," Biochem J., vol. 247, pp. 707-713, 1987.

[4] J. Aiyar, et al., "Reaction of chromium (VI) with glutathione or with hydrogen peroxide: identification of reactive intermediates and their role in chromium (VI)-induced DNA damage," Health Perspect, vol. 92, pp 53-62, 1991.

[5] D. Bagchi, et al., "Cytotoxicity and oxidative mechanisms of different forms of chromium," Toxicology, vol. 180, pp. 5-22, 2002.

[6] T. J. O'Brien, et al., "Complexities of chromium carcinogenesis: role of cellular response, repair and recovery mechanisms," Mutat. Res., vol. 533, pp. 3-36, 2003.

[7] R. Shrivastava, et al., "Effects of chromium on the immune system," FEMS Immunology and Medical Microbiology, vol. 34, pp. 1-7, 2002.

[8] J. L. Marnett, "Lipid Peroxidation-DNA damage by malondialdehyde," Mut Res, vol. 424, pp. 83-95, 1999.

[9] Kasai H., "Analysis of a form of oxidative DNA damage, 8-hydroxy deoxyguanocine, as markers of cellular oxidative stress during carcinogenesis," Mutat Res, vol. 387, pp. 147-63, 1997.

[10] Ames B. N., "Endogenous oxidative DNA damage, aging and cancer," Free Radic Res Commum, vol. 7, pp. 121-8, 1989.

[11] X. H. Zhang, et al., "Chronic occupational exposure to hexavalent chromium causes DNA damage in electroplating workers," BMC Public Health, vol. 11, pp. 224, 2011.

[12] P. Kakkar, et al., "Biological markers for metal toxicity," Environ Toxicol an Pharmacol, vol/issue: 19(2), pp. 33549, 2005

[13] M. I. Greenberg, et al., "Occupational, Industrial and Environmental Toxicology," second edition, Philadelphia, Mosby, 2003.

[14] Agency for Toxic Subtances and Disease Registry (ATSDR), "Toxicological Profile for Chromium," US Department of Health Human Services, Public Health Service. Agency for Toxic substances and Disease Registry, Atlanta, 2012.

[15] Y. Setyaningsih, et al., "Detection urinary 8-hidroxydeoxyguanosine (8-OHdG) levels as a biomarker of oxidative DNA damage among home industry workers exposed to chromium," Procedia Environmental Sciences, vol. 23, pp. 290-296, 2015.

[16] M. V. Rao, et al., "Protective role of vitamin E on nickel and/or chromium induced oxidative stress in the mouse ovary," Food Chem Toxicol, vol. 47, pp. 1368-1371, 2009.

[17] Nordberg J. and Arner E. S., "Reactive oxygen species, antioxidants, and the mammalian thioredoxin system," Free Radic Biol Med, vol. 31, pp. 1287-1312, 2001.

[18] Nielsen F., et al., "Plasma Malondialdehyd as biomarker for oxidative Stress: Reference interval and Effects of Life-style Factors," Clin Chem, vol/issue: 43(7), pp. 1209-1214, 1997.

[19] Hirano T., et al., "Formation of 8-Hydroxyguanine in DNA by Aging and Oxidative Stress," in Cutler RG, Packer L, Bertran J, Mori A, editors. Oxidative Stress and Aging, Birkhauser Verlag, Basel, Switzerland, pp. 69-76, 1995.

[20] B. P. Patel and U. M. Rawal, "Tobacco, antioxidant enzymes, oxidative stress, and genstic susceptibility in oral cancer," Am. J. Clin. Oncol, vol. 31, pp. 454-459, 2008.

[21] M. Lodovici and E. Bigagli, "Biomarkers of induced active and passive smoking damage," Int J Env Res Public Health., vol. 6, pp. 874-888, 2009.

[22] D. Ziech and Franco R., "Reactive Oxygen Species (ROS) - Induced genetic and epigenetic alterations in human carcinogenesis," Mut Res., vol. 711, pp. 167-173, 2011.

[23] Lecomte E., et al., "Effect of alcohol consumption on blood antioxidant nutreients and oxidative stres indicators," Am, J Clin Nutr, vol. 40, pp. 255-61, 1994.

[24] WHO, "The Role of Occupational Health Services in the Promotion of Work Ability and Health," Report on a WHO Consultation Turku, Copenhagen, 1987. 